University of Nebraska - Lincoln

DigitalCommons@University of Nebraska - Lincoln

2013

Patron-Driven Acquisition and Circulation at an Academic Library: Interaction Effects and Circulation Performance of Print Books Acquired via Librarians' Orders, Approval Plans, and Patrons' Interlibrary Loan Requests

\author{
David C. Tyler \\ University of Nebraska - Lincoln, dtyler2@unl.edu \\ Christina D. Falci \\ University of Nebraska-Lincoln, cfalci2@unl.edu \\ Joyce C. Melvin \\ University of Nebraska-Lincoln, jmelvin1@unl.edu \\ MaryLou Epp \\ University of Nebraska-Lincoln, mepp1@unl.edu \\ Anita M. Kreps \\ University of Nebraska-Lincoln, akreps1@unl.edu \\ Follow this and additional works at: https://digitalcommons.unl.edu/libraryscience \\ Part of the Applied Statistics Commons, and the Institutional and Historical Commons
}

Tyler, David C.; Falci, Christina D.; Melvin, Joyce C.; Epp, MaryLou; and Kreps, Anita M., "Patron-Driven Acquisition and Circulation at an Academic Library: Interaction Effects and Circulation Performance of Print Books Acquired via Librarians' Orders, Approval Plans, and Patrons' Interlibrary Loan Requests" (2013). Faculty Publications, UNL Libraries. 292.

https://digitalcommons.unl.edu/libraryscience/292

This Article is brought to you for free and open access by the Libraries at University of Nebraska-Lincoln at DigitalCommons@University of Nebraska - Lincoln. It has been accepted for inclusion in Faculty Publications, UNL Libraries by an authorized administrator of DigitalCommons@University of Nebraska - Lincoln. 


\title{
Patron-Driven Acquisition and Circulation at an Academic Library: Interaction Effects and Circulation Performance of Print Books Acquired via Librarians' Orders, Approval Plans, and Patrons' Interlibrary Loan Requests
}

\author{
David C. Tyler, Christina Falci, Joyce C. Melvin, \\ MaryLou Epp, and Anita M. Kreps \\ University of Nebraska-Lincoln, Lincoln, Nebraska \\ Corresponding author - David C. Tyler, Reference Librarian, University Libraries, \\ University of Nebraska-Lincoln, Lincoln, NE 68588-4100; email dtyler2@unl.edu
}

\begin{abstract}
Numerous publications on patron-driven acquisition (PDA) for print books and similar materials have reported that patronrequested materials circulate more. Tying circulation to selector may be failing to address the complex of factors that contributes to items' circulation. In the present study, the authors revisit a PDA program's data and to determine whether PDA print books' circulation advantage persists when the potential interactions of several additional variables are taken into account. As with prior studies, library patrons were significantly better predictors of circulation than were librarians or approval plans. However, librarians proved to be significantly better predictors than were approval plans.
\end{abstract}

Keywords: patron-driven acquisition, patron-initiated collection development, interlibrary loan, circulation, multiple regression

\section{Introduction}

Librarians have been touting, or at least toying with the idea of, some form of demand- or patron-driven acquisition (PDA) program for at least a century 
(Chadwell 2009; Dana 1896; Holley and Ankem 2005; Hostetler 2010; Hulsey 2003; Jackson 1989; Peasgood 1986; Pritchard 1980; Rathbone 1909; Rawlinson 1981). However, it would appear that it was not until the past decade or two, perhaps when PDA was tied to interlibrary loan (ILL), that interest in PDA truly proliferated, producing a flurry of books, articles, reports, and presentations in the library literature (Hostetler 2010; Nixon, Freeman, and Ward 2010; Tyler 2011; Way and Garrison 2011) and becoming "one of the most discussed ideas in the world of library collections" (Lugg 2011, 7).

In rapidly short order, the library literature has gone from suggesting that acquisitions or collection development will, could, or should be part of the future of ILL (Alder 2007; Chadwell 2009; Egan 2007; Hodges, Preston, and Hamilton 2010; McHone-Chase 2010; Murphy and Rupp-Serrano 1999; Oberlander 2006; Posner 2007; Reighart and Oberlander 2008; Richey 2010; Watson 2004) to asserting that PDA and purchase-on-demand (POD)-style programs have largely proven themselves and are well on their way toward becoming advisable, established, necessary, standard, and/or "more sane" practice (Anderson 2010; Dillon 2011; Fischer et al. 2012; Hussong-Christian and Goergen-Doll 2010b; Jones 2011; Levine-Clark 2011; Miller 2011; Nixon et al. 2010; Schroeder 2012; Tyler 2011; Way and Garrison 2011). There certainly seems to be evidence for a burgeoning widespread adoption of PDA for print materials, for although long-established programs are still somewhat uncommon, pilot and test programs, as well as libraries on the verge of launching them, appear to be legion (Carlisle Fountain and Frederiksen 2010; Lenares and Delquie 2010; Osorio 2011; Wexelbaum and Heinrich 2011).

In fact, adoption of and enthusiasm for PDA has apparently grown so great as to prompt a certain amount of recent introspection, if not hand-wringing, over whether selection might be dead (Anderson 2011); whether collection development librarians might be becoming obsolete (Hodges et al. 2010; Osorio 2011); whether the librarian-patron power dynamic in the area of collection development may be ineluctably shifting to the disadvantage of the former, particularly where influence over the materials budget is concerned (Corbett 2011; Lenares and Delquie 2010; Lugg 2011; Miller 2011; Smith 2011); whether librarians with collection development responsibilities might more profitably turn their attentions elsewhere to other, "higher-order" activities (Bracke, H’erubel, and Ward 2010; Dillon 2011; Levine-Clark 2011; Lugg 2011; Miller 2011); and whether PDA, as a "disruptive technology," will "fundamentally transform decades of library practice, along with longestablished relationships among publishers, book vendors, libraries, and library users" (Lugg 2011, 7).

Librarians' enthusiasm for PDA, at least where print materials are concerned, seems to be warranted, for the results reported in the literature seem almost universally favorable (Tyler 2011). ${ }^{1}$ For example, despite early concerns that patrons would be requesting via untested PDA programs books whose utility and value were unknown and unproven (Kuhn 2004; Rottmann 1991), the literature has reported 
that patrons have proven generally to be in favor of PDA programs and/or to have endorsed the value of PDA books upon receipt (Alder 2007; Anderson et al. 2010; Brug and MacWaters 2004; Chan 2004; Clendenning 2001; Comer and Lorenzen 2007; Foss 2007; Goergen-Doll and Hussong-Christian 2011; Hussong-Christian and Goergen- Doll 2010a, 2010b, 2011; Reynolds et al. 2010; Ward 2002; Ward, Wray, and Debuz-López 2003). In addition, despite librarians' fears that patrons would select quirky or inappropriate materials (Comer and Lorenzen 2007; Lenares and Delquie 2010; Price and McDonald 2009; Rottmann 1991; Shen et al. 2011; Tyler et al. 2010), various studies have concluded that the bulk of PDA acquisitions - actual or potential-have been collection-appropriate, worthy of purchase, and/or the sort of material that librarians would themselves likely have purchased had they sufficient funds (Allen et al. 2003; Anderson et al. 2002, 2010; Bracke 2010; Chan 2004; Cornell University Library 2007; Gee and Shirkey 2010; Hodges et al. 2010; Reynolds et al. 2010; Ruppel 2006; Shen et al. 2011; Tyler et al. 2010; Ward 2002; Ward et al. 2003; Way 2009). But by far the most positive aspect of PDA most frequently and consistently reported in the library literature has been that the print books and other similar materials (print theses and dissertations, proceedings, and so forth) requested by patrons and purchased through the programs circulate often much more than do books acquired via traditional avenues, such as approval plans or librarians' orders (Tyler 2011).

At this juncture, librarians' enthusiasm for PDA sometimes falters and protests arise that the situation cannot be so very simple: that is, that allowing patrons to order books in and of itself predicts higher levels of circulation. The not infrequently offered counterargument demands that several characteristics of the books and/or aspects of the institution must determine the amounts or rates of circulation, ${ }^{2}$ and the authors of the PDA literature, by having focused solely upon who ordered the books, have fallen victim to something like a "streetlight effect" (i.e., an observational bias wherein one looks for evidence where it would be most easily seen [Freedman 2010a, 2010b]). Certainly, it would seem possible that the correlative relationship between the elevated amounts of circulation experienced by the books in question and who ordered or selected the books could be more complex than has been reported in the literature thus far. In fact, with further analysis, it may be that other, as yet uncontrolled factors, could account for the reported differences in circulation, and the order type-circulation relationship could very well prove to be spurious.

\section{Review of Literature}

For the above two-part critique of the PDA literature to warrant attention requires two conditions in the library literature: first, there would have to be evidence in the literature on book circulation or use that supported the contention that there were likely correlates for circulation other than type of book order, and sec- 
ond, the analysis of circulation in the PDA literature would have to have failed to address these other correlates or have failed to address them with sufficient analytical depth. It would be impracticable to review comprehensively the library literature on circulation and other forms of book use, as evaluations of the collection that include circulation and/or use have been among the more frequent types of library evaluation, which has resulted in a very large literature (Bonn 1974). In fact, in 1969, Jain had estimated that the number of "published and unpublished studies concerning the use of books, journals, and library facilities is well over 700" (p. $245)$. With the advent of sophisticated automated data collection methods, one can only imagine how many studies are currently extant. Fortunately, in addition to being very large, this literature also has the virtue of being repetitious (Bonn 1974), so it should be unnecessary to survey the whole of the literature in order to find some evidence that circulation/use may correlate with something other than order type.

A quick glance at the library literature suggests that publications that explicitly identify or from which one may infer circulation correlates are fairly common. As has the PDA literature, many of the studies on circulation and use-both classic and current-have found relationships between circulation/use and books' selectors (Davidson 1943; Ellis et al. 2010; Evans 1970; Hardesty 1981; Pritchard 1980; Tucker 2009). A sizeable amount of research has also concluded or implied that relationships exist between circulation/ use and books' subjects or Library of Congress (LC) classifications (Adams and Noel 2008; Aguilar 1986; Blecic 2000; Britten 1990; Bulick, Sabor, and Flynn 1979; Davidson 1943; Ellis et al. 2010; Fenske 1994; Fussler and Simon 1969; Grigg et al. 2010; Knievel, Wicht, and Connaway 2006; Lancaster 1982; Lotlikar 1997; Mills 1982; Mouyal 2005; Ochola 2002; Peasgood 1986; Tucker 2009). Some of this research has further suggested that subject/circulation may also correlate with other factors, such as total number and total cost of books published in a topical area, the number of faculty members in pertinent academic departments, and the number of credit hours taught in these departments (McGrath, Huntsinger, and Barber 1969); academic departments and their numbers of students receiving grades (Jenks 1976); or academic departments and their numbers of classes offered (Mouyal 2005). A number of studies have also suggested relationships between circulation/ use, age of materials, and/or materials' periods of availability (Adams and Noel 2008; Bates 1971; Bulick et al. 1979; Burrell 1985; Davidson 1943; Fussler and Simon 1969; Hardesty 1981). Other works have argued for relationships between early and later rates of circulation (Burrell 1986; Fussler and Simon 1969; Jain, Leimkuhler, and Anderson 1969), circulation and inhouse use (Bulick et al. 1979; McGrath 1971), circulation and publisher (Adams and Noel 2008), circulation and books' genre (Davidson 1943), and circulation and books' language (Bulick et al. 1979; Fussler and Simon 1969). So, quite clearly, circulation is potentially a complex, multifaceted subject. 
The question, then, is not whether there are other likely correlates for circulation, but whether the PDA literature for print books and similar materials has addressed this potential complexity and done so with appropriate methods. Unfortunately, the answer would appear to be that the PDA literature has failed to address this complexity. In reporting their results, many PDA studies have merely offered the reader the number or percentage of PDA books that have circulated, sometimes with figures for traditionally acquired books included for purposes of comparison and sometimes not (Allen et al. 2003; Anderson et al. 2002; Brug and MacWaters 2004; Campbell 2006; Crane 2011; Houle 2004; Perdue and Van Fleet 1999; Pritchard 1980; Reynolds et al. 2010; Teaff 2011; Ward 2002; Ward et al. 2003; Way 2009; ZopfiJordan 2008). Other studies have additionally offered the numbers or percentages of PDA books that have experienced multiple circulations (Allen et al. 2003; Anderson et al. 2002; Bombeld and Hanerfeld 2004; Brug and MacWaters 2004; Chan 2004; Houle 2004; Ward et al. 2003) or numbers of circulations subsequent to the books' having been returned to the library shelves by their initial ILL requestors (Comer and Lorenzen 2005; Nixon and Saunders 2010; Way 2009). A few studies, perhaps unkindly, have also drawn attention to the numbers or percentages of PDA and/or traditionally acquired books that have failed to circulate (Nixon and Saunders 2010; Tyler et al. 2010, 2011; Way 2009). Beyond this offering of raw data, a small number of studies have presented the average circulations of PDA books (Allen et al. 2003; Campbell 2006; Chan 2004; Hodges et al. 2010; Ward et al. 2003; Way 2009), and several have presented these averages in comparison with the average circulations of traditionally acquired books (Gibson and Kirkwood 2009; Goergen-Doll et al. 2010; Hussong-Christian and Goergen-Doll 2010a, 2011; Nixon and Saunders 2010; Perdue and Van Fleet 1999; Schroeder 2012; Spitzform 2011a, 2011b; Ward 2011; Ward et al. 2003). However, to the best of the authors' knowledge, as yet only a single article on print PDA books has offered a statistical test of the differences in circulation rates between order types, a single-factor nonparametric test of annual turnover rates by order type which, obviously, failed to address other potential correlates (Tyler et al. 2010). Furthermore, just one or two PDA articles have noted potential correlates other than order type-for example, Nixon and Saunders (2010) noted variability in circulation performance that could be tied to the rank status of the requestor or to LC classifications, and Way (2009) concluded that holdings by peer libraries appeared to correlate positively with circulation-but these articles do not appear to have provided statistical analyses. Thus, it would seem that the PDA literature on print books and similar materials to date has provided an overly narrow and insufficiently analytical study of the relationship between order type and circulation, so the current study should be a worthwhile addition to the PDA literature. 


\section{Background}

Chartered in 1869, the University of Nebraska-Lincoln (UNL) is a land-grant university that serves as the comprehensive public university for the State of Nebraska (Knoll 1995; Manley 1969). The UNL University Libraries - which comprise the Don L. Love Memorial Library and six branch libraries across two campuses and house over three million print volumes (University of Nebraska-Lincoln Libraries 2011) ${ }^{3}-$ operated a small POD-style PDA program through its ILL department on a continuing trial basis over five fiscal years (from July to June, 2003/ 2004 to 2007/2008). While the program was in operation, UNL enrolled each fall an average of 22,221 students, of whom an average of 4,731 were graduate and postgraduate professional students, and UNL employed on average 1,954 faculty members (University of Nebraska-Lincoln, Office of Institutional Research and Planning 2005-2009). The UNL University Libraries' PDA program had been co-initiated by the ILL department and the Collection Development Committee and was implemented at the beginning of the 2003 fiscal year. In implementing the program, the libraries adopted some purchasing guidelines, as has generally been the case with the many similar programs that have appeared in the literature (Anderson et al. 2010; Carlisle Fountain and Frederiksen 2010; Herrera and Greenwood 2011; Nixon et al. 2010; Tyler 2011; Wexelbaum and Heinrich 2011), to ensure that materials purchased through the program would be suitable additions.

\section{Methodology}

During the five-plus-year period that the libraries' ILL POD program was in its pilot phase, the libraries acquired 69,941 print volumes for the circulating collection. These books were acquired via one of five order or selection modes: book vendors' selections for the approval plan, librarians' orders, the lost book replacement fund, targeted donor bequests, and PDA. Upon reviewing the data set, the authors found it necessary to make some reductions. For the current study, the authors have elected not to include the books purchased via the lost book replacement fund because a sizeable percentage of the books thus acquired were manifestly different from books acquired via the other modes (i.e., rather than being newly published, many were replacement copies of older, often highly circulated, works). The authors also elected not to include the books purchased via targeted donor bequests simply because $74 \%$ of these books had yet to circulate even once (Tyler et al. 2011).

In addition to information on who was responsible for ordering/selecting the books in question (i.e., "order type," the study's independent variable), several other potentially pertinent pieces of information were recorded by the libraries dur- 
ing the interval: how many times the books circulated (i.e., "circulation," not including reserve circulations), how many years the books were available for circulation (i.e., "years available"), how much was paid for each book (i.e., "book price"), and the books' LC call numbers. Circulation will, of course, be the study's dependent variable, and the authors will be employing the others as control variables that may alter or offer alternative explanations for the PDA books' circulation advantage. Unfortunately, there were far too many LC call numbers to allow for analysis, so the authors grouped the books into their one-, two-, and three-letter LC classes, which reduced the number of subject categories from several thousand to 256. Upon further review, it came to light that readership and genre guidelines for the ILL POD program blocked the LC classification for children's literature (i.e., PZ), so books from this class were disallowed.

Two hundred fifty-five classes, unfortunately, still proved too unwieldy, so the authors grouped the books into twenty-four broad subject areas in accordance with UNL University Libraries' collection assessment practices (Tyler et al. 2009). Testing of the subject areas discovered that six of them still had too few PDA purchases to allow for analysis, so books from these subjects were also removed. These winnowing procedures left the authors with 63,732 books for analysis, $91.1 \%$ of the original data set, and $95.1 \%$ of the books purchased/selected by the book vendors, librarians, and ILL patrons.

General characteristics of the study's data set, excluding subject area data, are presented in Table 1. The final two partial columns of the table require some explanation. When questioning the superior circulation performance of PDA books, librarians not infrequently point out that the PDA books usually, and unfairly, begin their circulating careers with the advantage of a guaranteed first circulation to their requesting ILL patrons (Tyler et al. 2011). Recent research from Purdue University's POD program has shown that PDA books there outcirculated traditionally acquired books in terms of average circulations per book after a decade on the shelves even if their initial circulations had been subtracted (Nixon and Saunders 2010), so the authors of this study, in order to preemptively answer this criticism and to possibly replicate Purdue's findings, have followed suit and prepared a variation of the ILL PDA data that includes only circulations subsequent to the books' return by their initial requestors (i.e., "interlibrary loan subsequent circulations only" or ILLSCO). The main body of the analysis to come, unless otherwise indicated, will employ the ILLSCO data subset, revealing thereby whether the PDA books outperformed the book vendors' selections and librarians' purchases even without their initial circulations to their ILL requestors.

As was noted above, a study that employed the entire set of books but that had just a single correlate was published earlier (Tyler et al. 2010). That study analyzed the books' annual turnover rates (i.e., average rate of annual circulation), which, after some testing, was found not to conform to a known distribution, which necessitated 
Table 1. General Characteristics of the Data Set ${ }^{a}$

\begin{tabular}{lrrrrrr}
\hline & & & & & & Total \\
& Total & Book Vendor & Librarian & ILL & ILLSCO & ILLSCO \\
\hline Books & 63,732 & 35,194 & 27,134 & 1,404 & & \\
Circulations & 78,697 & 37,299 & 37,266 & 4,132 & 2,747 & 77,312 \\
Mean & 1.2348 & 1.0598 & 1.3734 & 2.9430 & 1.9566 & 1.2131 \\
SD & 1.8437 & 1.5821 & 2.0586 & 2.3657 & 2.3516 & 1.8288 \\
Min. & 0 & 0 & 0 & 0 & 0 & 0 \\
Max. & 49 & 25 & 49 & 20 & 19 & 49 \\
Years Available & 200,807 & $110,565.6$ & $85,966.3$ & $4,275.1$ & & \\
Mean & 3.1508 & 3.1416 & 3.1682 & 3.0449 & & \\
SD & 1.3131 & 1.3604 & 1.2519 & 1.2511 & & \\
Min. & 0.0833 & 0.0833 & 0.1667 & 0.5833 & & \\
Max. & 5.6667 & 5.4167 & 5.6667 & 5.25 & & \\
Book Price & $\$ 3,245,681.51$ & $\$ 1,760,561.28$ & $\$ 1,404,094.74$ & $\$ 81,025.49$ & & \\
Mean & $\$ 50.93$ & $\$ 50.02$ & $\$ 51.75$ & $\$ 57.71$ & & \\
SD & $\$ 39.16$ & $\$ 27.85$ & $\$ 50.04$ & $\$ 41.10$ & & \\
Min. ${ }^{\mathrm{c}}$ & $\$ 0.00$ & $\$ 0.00$ & $\$ 0.00$ & $\$ 0.00$ & & \\
Max. ${ }^{\mathrm{d}}$ & $\$ 839.27$ & $\$ 348.75$ & $\$ 839.27$ & $\$ 284.05$ & & \\
\hline
\end{tabular}

a. Where appropriate, values are rounded.

b. For the later statistical analyses, circulations was truncated, with a maximum of 30 .

c. Twelve books were recorded, no doubt erroneously, as having prices of $\$ 0.00$.

d. For the later statistical analyses, book price was truncated, with a maximum of $\$ 500.00$.

the employment of a nonparametric method (Tyler et al. 2010). In the initial stages of this study, the authors again attempted to employ annual turnover rates, but with the proposed correlates in place, the authors were unable to coax the models into convergence. Also, employing the annual turnover rate meant that one of the control variables (i.e., years available) was present in the dependent variable, which would be undesirable for obvious reasons.

Previous work suggested that the distribution of circulation should take a Poisson or negative binomial form (Bulick et al. 1979; Burrell 1988, 1990; Fussler and Simon 1969) and that "NB processes [would] give the best predictions for collections with ageing" (Burrell 1990, 59). Certainly, the profile of the relative frequency distribution of this study's data would incline one to conclude likewise (see Figure 1), and the authors hoped to have better luck working with a known distribution as well as to remove a confounding control variable from the dependent variable. Unfortunately, the assumption of the negative binomial distribution for circulation has been criticized on grounds of goodness of fit (Tague and Ajiferuke 1987), so the authors found it necessary to compare the model fit across four estimation strategies, Poisson and negative binomial, with and without zero-inflation for each type. A chi-squared test determined that the negative binomial form without zero-inflation was appropriate for the study's data. Significant dispersion parameters further signified the prefer- 


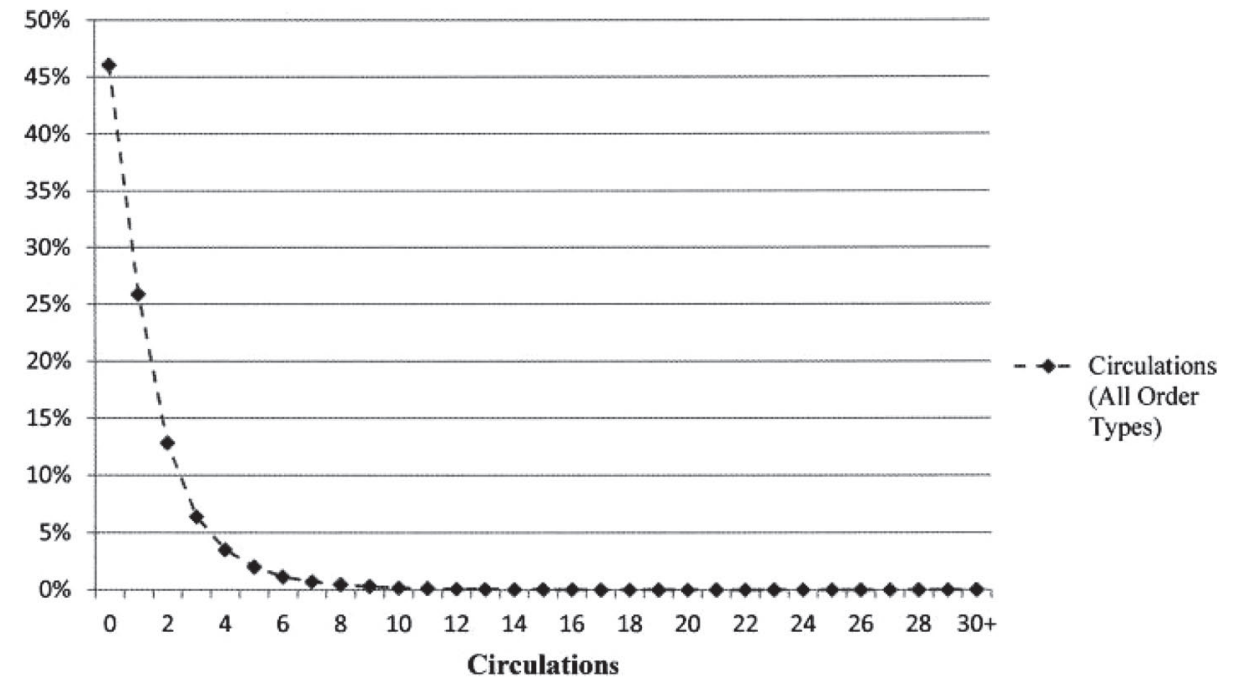

Figure 1. Relative frequency distribution of circulations. Note: ILLSCO data, rather than unadjusted ILL data, were employed in the figure; the dashed line connecting data points is merely a guide for the eye and does not indicate a continuous variable.

ence for negative binomial over Poisson, and the presence of a significantly negative inflated intercept parameter ruled out the need for zero-inflation (Erdman, Jackson, and Sinko 2008). Finally, employing this distribution did produce the necessary convergence in the models.

The data analytic steps to test this study's research questions first entailed exploring the bivariate association between order type and circulations (see Appendix: Model 1). From there, we examined this same association in a multivariate context controlling for years available, book price, and subject area (see Appendix: Model 2). The last two models in the Appendix explore two distinct interaction effects: the first involving order type with book price (Appendix: Model 3) and the second involving order type with subject area (Appendix: Model 4). For this last model, the significance of the interaction terms does not make the explicit statistical test of interest in the study. Therefore, we conducted a series of customized hypothesis tests to assess mean differences in circulation across order type within each subject area. The results of these tests will be shown below in the section on Subject Area (Table 3).

\section{Results}

Interaction effects represent the combined effects of, potentially, several variables acting in concert with or upon a dependent variable, and the idea behind multiple regression is that these potential multiple effects should be studied, rather than the 
Table 2. Generalized Linear Model for Circulations by Order Type with a Bonferonni Adjustment $(N=63,732)$

\begin{tabular}{lccccccc}
\hline & \multicolumn{9}{c}{ Order Type } \\
\cline { 2 - 8 } & $\begin{array}{c}\text { Interlibrary Loan } \\
\text { PDA (I) } \\
\text { Mean }\end{array}$ & $\begin{array}{c}\text { Book Vendor } \\
\text { Circulations }\end{array}$ & Mean & Librarian Orders & & & \\
\hline No. of Circulations & 2.94 & 1.06 & I & 1.37 & IB & 865.6 & $* * *$ \\
No. of Circulations & 1.96 & 1.06 & I & 1.37 & IB & 349.1 & $* * *$ \\
(ILLSCO) & & & & & & & \\
\hline
\end{tabular}

See Appendix, Model 1, for regression coefficients.

$\mathrm{B}=$ Mean for librarian is significantly different from book vendor mean $(p<.05)$.

$\mathrm{I}=$ Mean for book vendor or librarian is significantly different from interlibrary loan mean $(p<.05)$.

isolated effects of single variables, because, when interaction effects are present, correlations between individual variables studied in isolation may be incomplete or misleading (Stevens 2000; Vogt 1999). The aforementioned question, then, that prompted our colleagues' objections to the findings of earlier PDA studies and that motivated this study would be, "Do the earlier studies provide incomplete or misleading analyses?" With respect to the prior, single-factor nonparametric test of the full data set, the answer would appear to be both "no" and "yes".

\section{Order Type}

The earlier study by Tyler et al. (2010) had found that the annual turnover rates of the ILL PDA books were significantly higher than were those of the book vendors' selections and the librarians' purchases. The study also found that the rates of the latter selectors/purchasers were comparable. The librarians' books consistently outperformed the book vendors', but seemingly not significantly so.

As Table 2 shows, with the circulation means left unadjusted, the ILL books significantly outcirculated both the librarians' and the book vendors' books. ${ }^{4}$ In fact, if one were to review the lower row of the table, one would see that the ILL PDA books persisted in outcirculating the librarians' and vendors' books even without their initial circulations to their requesting ILL patrons, which duplicates the findings of the librarians at Purdue University (Nixon and Saunders 2010). What the table reveals and what the prior study had obscured is that the librarians' books outcirculated the vendors' books by a statistically significant amount as well. (Note: multiple regression, while a powerful tool, is also a very complex topic, one with which some librarians may be less than familiar. So, to assist with the interpretation of the findings, the authors have elected to supply graphs as well as tables [see Figure 2]. Readers interested in the regression coefficients may refer to the Appendix). Please keep in mind, again, that throughout the remainder of the article the authors will be employing the 


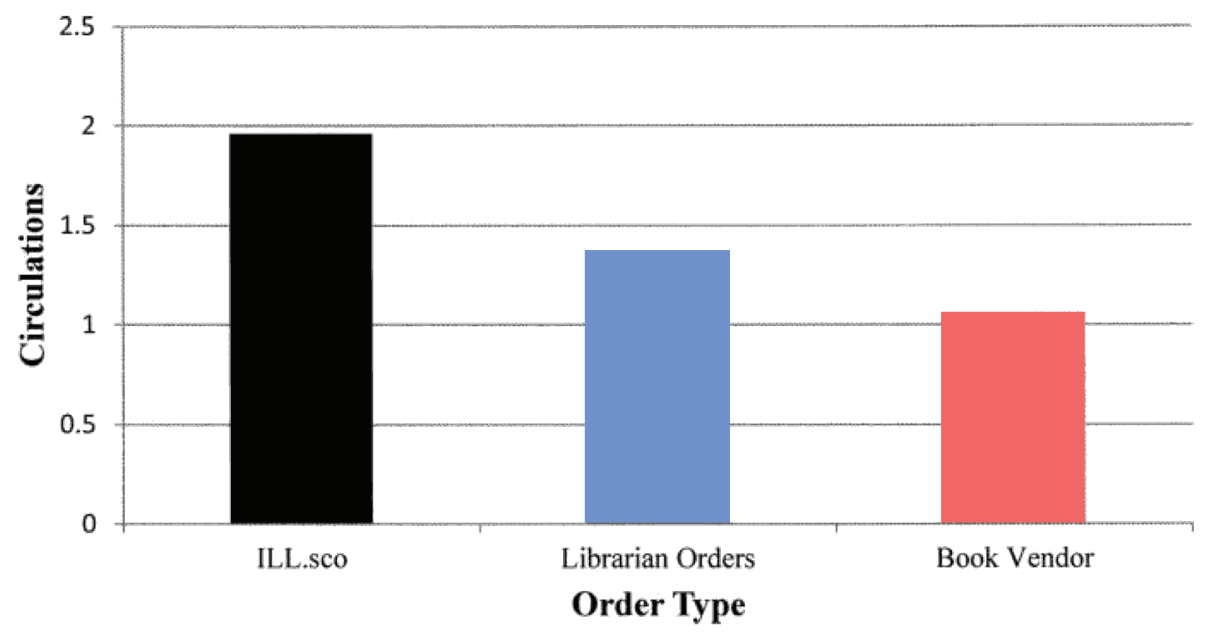

Figure 2. Predicted circulation means by order type. Note: See Appendix, Model 2, for regression coefficients.

ILLSCO data to demonstrate that the ILL PDA books outperformed the librarians' and the book vendors' even after having been returned to the shelves by their initial ILL requestors, which would suggest that the ILL PDA books were either of interest to library patrons other than their initial requestors or that they were needed by their initial requestors multiple times.

Having established that statistically significant differences do exist between the three order types, it would be appropriate to address the study's second research question and answer our colleagues' objections: "Do these statistically significant differences persist when the interaction effects of the several control variables are included in the model?" As Figure 2 illustrates, the answer is that they quite clearly do, for the differences between the unadjusted mean circulations reported in Table 2 and the predicted means shown in Figure 2 are infinitesimal (ILLSCO = 1.94; librarian orders $=1.38$; book vendor $=1.06$ ). In fact, some of the differences were small enough to be entirely masked at the hundredths level by rounding. Thus, the differences between the means did not get any smaller with the inclusion of the control variables in the model. In fact, in comparing model 1 to model 2 in the Appendix, one can see that there actually was a slight increase in the differences between the means, albeit of an amount likely to prove insignificant.

\section{Years Available}

Before concluding the study, it would be worthwhile to examine the behavior of the other variables in the model, the control variables years available, subject area, and book price. The effect of time on circulation is, of course, already well-established in the library literature. Books tend to circulate fairly early in their shelf lives or not at 
Table 3. Predicted Circulation Means from Negative Binomial Regression with Subject Area and Order Type Interaction $(N=63,732)$

\begin{tabular}{|c|c|c|c|c|c|c|c|c|}
\hline \multirow[b]{2}{*}{ Subject Area } & \multicolumn{2}{|c|}{$\begin{array}{c}\text { Interlibrary } \\
\text { Loan }_{\text {sco }} \\
\end{array}$} & \multicolumn{3}{|c|}{$\begin{array}{c}\text { Book } \\
\text { Vendor }\end{array}$} & \multicolumn{3}{|c|}{ Librarian } \\
\hline & Mean & $n$ & Mean & & $n$ & Mean & & $n$ \\
\hline Philosophy & 1.61 & 44 & .77 & I & 982 & .89 & IB & 533 \\
\hline Religious Studies & 1.13 & 71 & .88 & & 1,401 & .98 & B & 596 \\
\hline History & 1.49 & 166 & 1.08 & I & 5,147 & 1.00 & I & 1,860 \\
\hline Music & 2.14 & 23 & 1.85 & & 614 & 2.14 & & 569 \\
\hline Art, Architecture, and Photography & 1.96 & 126 & 1.19 & I & 1,585 & 1.99 & в & 2,107 \\
\hline Language and Literature & 1.62 & 165 & .91 & I & 5,819 & 1.14 & IB & 6,699 \\
\hline Library and Information Sciences & 1.34 & 18 & 1.09 & & 80 & 1.27 & & 192 \\
\hline Psychology & 2.65 & 46 & 1.32 & I & 452 & 1.90 & IB & 439 \\
\hline Social Sciences and Statistics & 2.81 & 9 & 2.30 & & 67 & 2.41 & & 153 \\
\hline Business and Economics & 1.81 & 106 & .96 & I & 3,328 & 1.21 & IB & 2,140 \\
\hline Sociology & 2.17 & 152 & 1.23 & I & 2,318 & 1.58 & IB & 2,330 \\
\hline Political Science & 1.63 & 45 & .94 & I & 1,448 & 1.18 & IB & 886 \\
\hline Law & 1.64 & 44 & 1.01 & I & 584 & .99 & I & 185 \\
\hline Education & 2.11 & 47 & 1.05 & I & 1,421 & 1.43 & IB & 1,787 \\
\hline Sciences and Mathematics & 2.60 & 148 & 1.24 & I & 5,085 & 1.49 & IB & 2,573 \\
\hline Medicine & 2.44 & 125 & 1.16 & I & 1,222 & 1.57 & IB & 1,679 \\
\hline Agriculture & 2.06 & 10 & 1.04 & I & 552 & 1.29 & B & 1,153 \\
\hline Engineering and Technology & 1.73 & 59 & .86 & I & 3,089 & 1.67 & в & 1,199 \\
\hline
\end{tabular}

$\mathrm{B}=$ Mean for librarian is significantly different from book vendor mean $(p<.05)$.

$\mathrm{I}=$ Mean for book vendor or librarian is significantly different from ILLsco mean $(p<.05)$.

all (Bulick et al. 1979; Fussler and Simon 1969), and over the course of their shelf lives, after that initial period of peak circulation, average annual circulation tends to drop precipitously over the years (Bulick et al. 1979; Burrell 1985, 1986; Davidson 1943; Fussler and Simon 1969), although not necessarily regularly (Burrell 1987). This state of affairs should result in a positive correlation between time and total circulation and a negative correlation between time and the annual turnover rate. This study's data showed the expected small positive correlation between years available and circulation (see Appendix: Models 2-4), so this study's findings have nothing remarkable to contribute in this area.

\section{Subject Area}

The question likely to be of particular interest to subject librarians is whether the effects shown in Figure 2 persist across all subject areas or whether there is some variability in the results. Recent collection analysis from the University of Nevada, Las Vegas (UNLV) has concluded that, in their second year on the shelves, approval monographs in most subject areas circulate more than do monographs purchased 
by librarians with discretionary funds (Tucker 2009). A similar recent analysis at the University of Kansas found usage patterns to be much more mixed and to vary by subject (Ellis et al. 2010). Table 3 suggests that the pattern at the UNL University Libraries is fairly consistent across subject areas, with ILL PDA books performing significantly better than (or at least equal to) the librarians' purchases and the book vendors' selections in almost every category. ILL PDA's mean circulation performance was significantly better than the librarians' in eleven of the eighteen subject areas analyzed, and it was significantly better than the book vendors' in fourteen of eighteen areas. Unlike at UNLV, however, the UNL librarians' purchases performed significantly better than did the book vendors' selections in many areas, showing statistically significant differences in thirteen of eighteen subject areas.

In order to make the results more intelligible and to allow for easier comparison with Figure 2, the authors have reproduced Table 3 in Figure 3 as three subgraphs: an arts and humanities (Figure 3a), a social sciences (Figure 3b), and a sciences subgraph (Figure 3c). One can see from a review of the three subgraphs that the pattern established in Figure 2 is largely replicated across all subjects. Contraindicating points of particular interest in Figure 3a are the performances of "music" and of "art, architecture, and photography"; in Figure 3b, the performance of "social sciences and statistics" is similarly noteworthy. Earlier collection assessment at the UNL University Libraries had identified these areas as having relatively high amounts of circulation and circulations per volume (Tyler et al. 2009), so one would expect to see less variability in these subject areas. Also of note in Figure $3 \mathrm{~b}$ are two areas that do not quite fit the collection development model of the UNL University Libraries. First, "library and information sciences" is a subject area without a department or program at UNL, so the users of these materials are likely to be the librarians themselves, barring the occasional education major interested in becoming a media specialist. Second, "law" also is an odd case, in that the college has its own library elsewhere, so the books in this area were purchased to satisfy the law-related needs of non-law students. Thus, librarians purchasing in "law" were purchasing for the campus as a whole rather than primarily for a department, program, or college. The remaining subject areas, however, largely all have college, departmental, or program liaison librarians and reproduce the results reported in Figure 2, which would indicate that the effects found for the collection as a whole were generally replicated across the individual subject areas.

\section{Book Price}

Last, the authors will turn to the variable likely to be of most interest to collection managers and library administrators: price. For ease of discussion, the authors will simply produce a graph for the variable. As Figure 4 shows, when order type and book price are working together, with years available and subject area held constant, the correlation between circulations and book price is negative: as the price of a 


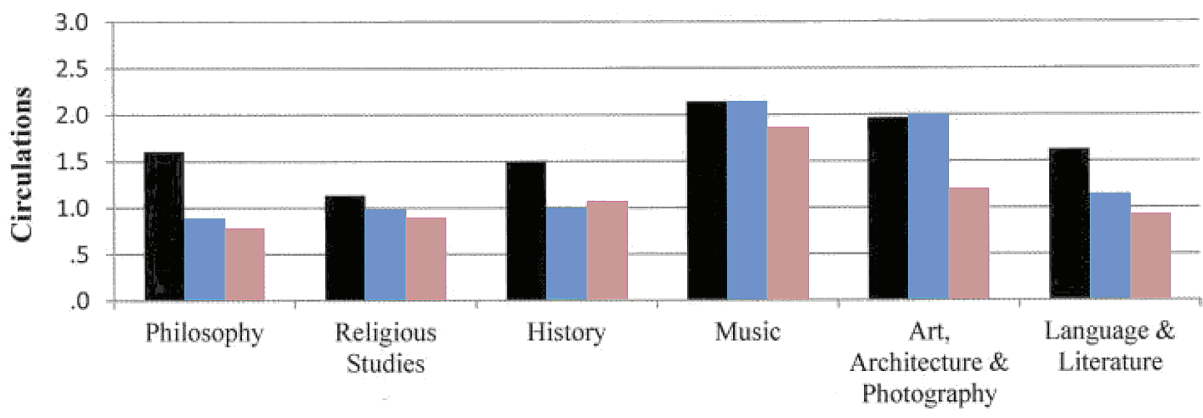

Figure 3a: Arts \& Humanities Subject Areas

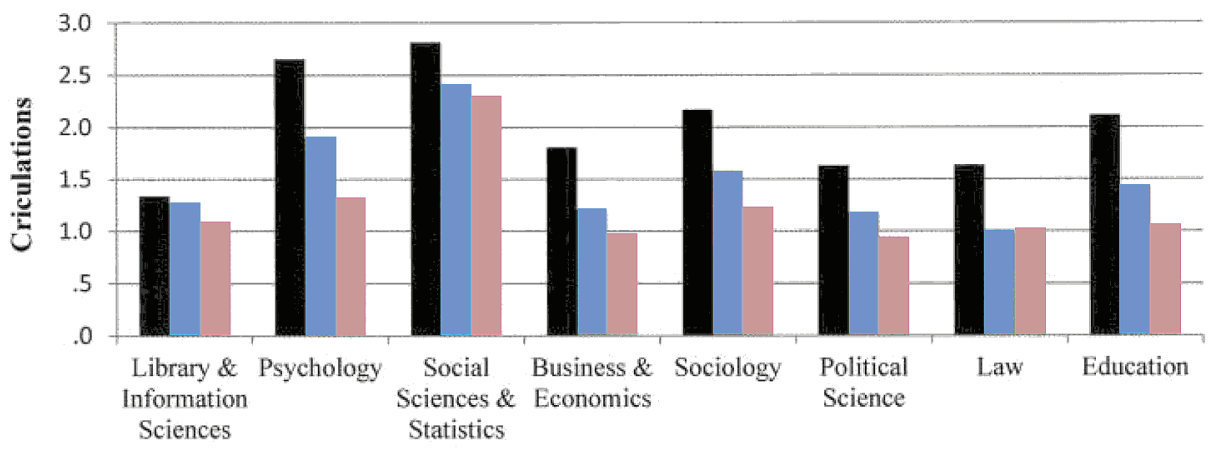

Figure 3b: Social Sciences Subject Areas

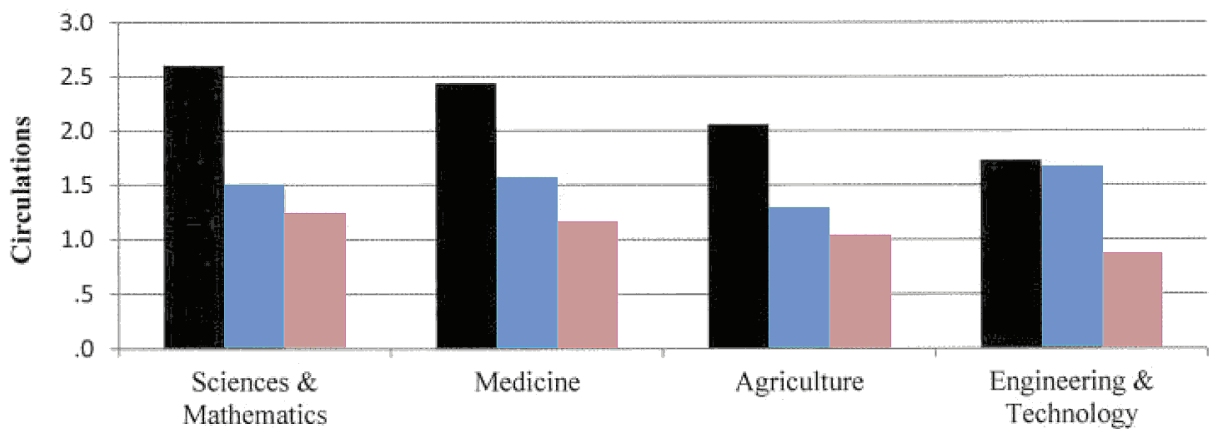

Figure 3c: Sciences Subject Areas

allesco Librarian Book Vendor

Figure 3. Circulations by order type and subject area. See Appendix, Model 4, for regression coefficients.

book increases, circulation decreases. Although the differences in the regression coefficients appear slight (see Appendix: Model 3), the slope for the ILL PDA purchases was still significantly different than the slope for the book vendors'; there was no significant difference between ILL PDA and the librarians' purchases (i.e., the ILL PDA books still circulate more, hence the higher starting point in the graph, but the slopes of the two lines were nearly parallel). 


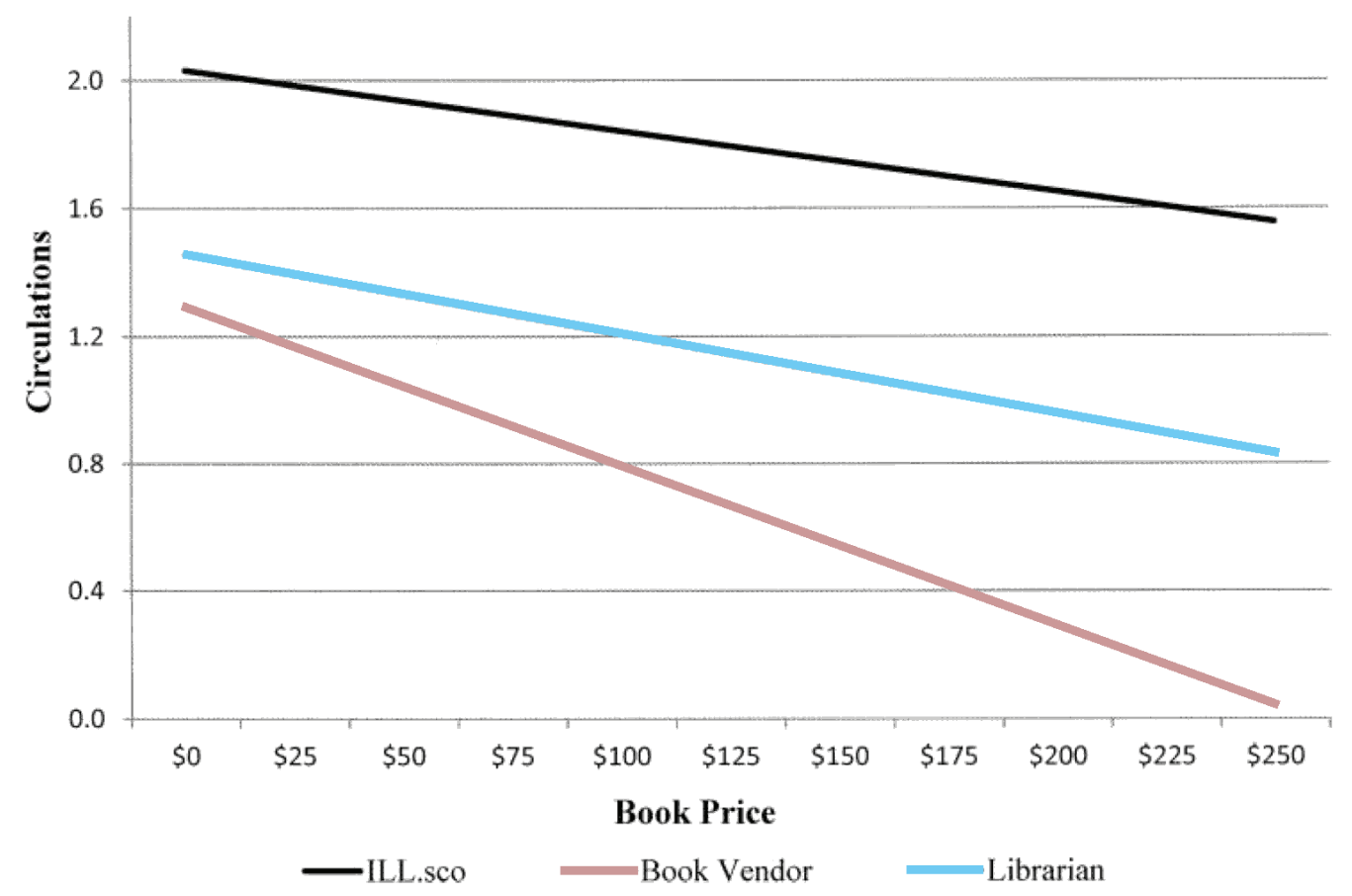

Figure 4. Effect of book price on circulations by order type. See Appendix, Model 3, for regression coefficients.

\section{Analysis}

With respect to collection development, a colleague has noted in the literature that "[b]uilding a library collection starts and ends with understanding the needs of library users, the institutional environment, trends in assigned disciplines, budgetary constraints, and evaluation [of] quality of content" (Anderson 2011). If circulation may be employed as a metric that expresses the needs of a library's users, then, as this colleague later concluded, it may be unwise to kill off the core activity of selection entirely at this juncture. Although the UNL POD program's patrons clearly anticipated their own and their fellow patrons' future needs better than did the librarians or book vendors, the librarians clearly anticipated the needs of patrons better than did the book vendors (see Figure 2). Before considering instituting radical changes to libraries' collection development programs based upon the PDA literature's findings, one should also keep in mind that, within this data set, the librarians and book vendors combined purchased over forty-four times as many books as did the ILL patrons and spent thirty-nine times as many library dollars.With the exception of Texas A\&M's program, the PDA programs reported on 
in the literature have been similarly sized (Tyler 2011). Thus, the positive effect of the UNL POD program on circulation is exciting and certainly supports the continuance of the program, but its overall impact on the UNL University Libraries' circulation totals has been small. If a library were considering abandoning librarian selection in favor of an acquisition model that employed just PDA and an approval plan, the findings of this study suggest that doing so could seriously harm the utility of the collection, either through increasing the relative impact of the poorer selector (i.e., approval plans) or through possibly increasing the relative impact of the better selector (i.e., PDA) past an as-yet-undiscovered point of diminishing returns. The model supported by this study's findings, rather, would suggest increasing both PDA and librarians' selection activities and reducing or limiting approval plan expenditures.

Of particular note to librarians with selection responsibilities should be the results reported for the several subject areas, for there may be hidden in the data a latent variable that argues for librarians' subject expertise and local knowledge and possibly even for the college or departmental library, at least where the arts and humanities are concerned. With respect to the latter point, the entire music collection and the entire architecture portion of "art, architecture, and photography" are housed in propinquitous college libraries that are overseen by librarians who have held their positions for decades and who are noteworthy for the strong relationships they have built with their liaison departments and programs. With respect to the former point, i.e., subject expertise and local knowledge generally, although they are not all entirely housed in departmental libraries, many of the other subject areas are served by librarians who have been in the field and/or in their particular positions for quite some time. A librarian serving the philosophy and the language and literature subject areas at UNL has been in the field since the 1970s. A number of the sciences' subject areas' librarians had been in the field or in their positions for decades when the data were collected, and, in fact, several retired between the collecting of the data and the authoring of this article. In the social sciences areas, one of the "youngsters" in the group, the sociology librarian, had been in his position for nine years. As a group, the UNL University Libraries' librarians very much know their fields and their particular liaison departments and programs, and one would be inclined to suggest that this knowledge could be manifesting itself in the circulation performance of the materials they have purchased.

This potential latent variable may also be manifesting itself in the book price/ circulation correlation. When discussing this issue with the authors, colleagues were of the opinion that the higher-priced books were likely to be more abstruse and to be intended for specialist audiences and that the lowerpriced books were likely to be those intended for undergraduate audiences and to have a broader appeal. If this is the case, then the slopes in Figure 4 should be a caution to collection managers and library administrators intent on removing librarians from 
the selection process. What Figure 4 suggests is that the UNL University Libraries should want its patrons to be selecting both less and more expensive items for the circulating collection, followed by the local librarians selecting more expensive items to meet the future needs of their liaison departments and programs. The entity that should not be selecting expensive items for UNL University Libraries is the approval plan.

A past argument in the library literature against turning over library selection to approval plans is that they do not provide access to all points of view and that they have an inherently pro-corporatist bias (Willett 1998). A much simpler argument against such outsourcing, and one made without recourse to ideology, is that book vendors demonstrably do not anticipate the needs of particular libraries' patrons, as expressed by circulations, as well as do the patrons themselves and the local librarians who serve them. The data here show that the more dollars that the UNL University Libraries have allowed book vendors to spend on high-priced books, the more these pricey items have failed to satisfy UNL patrons' needs.

\section{Limitations to the Study}

Obviously, with a single-site study, there is always the question of how generalizable the reported results may be. The numerous journal and magazine articles, book chapters, research reports, and conference presentations on academic libraries' PDA programs and the seeming universality of the circulation advantage enjoyed by PDA books suggest that the effect of order type on circulation is real and that, at least in the shorter term, library patrons are better predictors of what their fellow patrons will want to check out than are librarians and book vendors. Librarians proved themselves to be superior to book vendors at UNL, but recent research at UNLV and the University of Kansas suggests that the opposite could be true at some sites or that the effect might muddled by local factors at other locations (Ellis et al. 2010; Tucker 2009).

In essence, it is possible that there may be local factors not addressed by this study that impair the generalizability of specific effects. Several potential correlates were suggested by the library literature that were not included herein. Several of them may be dismissed out of hand: the UNL University Libraries do not purchase enough fiction or non-English language materials for genre or language to have a noticeable effect, for example. Publisher as a variable, however, may warrant further examination, for future configuration of the approval plan. Several studies had noted a correlation between the circulation of books in certain areas and the size and activity levels of pertinent academic departments (Jenks 1976; McGrath et al. 1969; Mouyal 2005), and it would certainly not strain the imagination to suppose that a university with a different arrangement of departments would see somewhat different behavior in the various subject areas. 
Finally, the authors would like to note that this study has limited itself to examining the circulation behavior of printed books in the library collection. There is a separate, somewhat parallel, and rapidly growing literature devoted to electronic books (e-books) and PDA. Much of this literature reports comparatively high circulation/use levels for PDA e-books that are very similar to what has been presented in the PDA literature on print materials (Carrico and Leonard 2011; Ferguson, Chan, and Lai 2008; Fischer and Wright 2010; Fischer et al. 2012; Hardy and Davies 2007; Hodges et al. 2010; Littman and Connaway 2004; Price and McDonald 2009; Slater 2009; Sutton 2003). This strong similarity, while encouraging, is no guarantee that the arguments, analyses, and conclusions presented here will apply without modification to PDA and e-books.

\section{Conclusion}

The results reported in this study should strengthen the widespread contention in the library literature that PDA books circulate more than do books acquired via librarians' orders or approval plans. The circulation-related superiority of the UNL University Libraries' PDA books reported by Tyler et al. (2010) in an earlier analysis persisted in this study even after several control variables were included in the circulation model and, impressively, even when the PDA books' circulations to their initial ILL requestors had been subtracted from the data set, which, notably, had also been the case at Purdue University (Nixon and Saunders 2010). Within this particular data set, the discovered circulation advantage was statistically significant and was present in almost all of the analyzed subject areas, which suggests that order type effects persisted across subject effects.

Perhaps the most noteworthy discovery was in the area where circulation and price intersect. One's first inclination, upon learning that circulation decreases as book price increases, might be to inquire somewhat facetiously of publishers and book vendors why libraries would want to pay more for books in order to receive less in the way of circulations. However, the more important point here, the authors believe, is that libraries should reconsider the configuration of their acquisition activities in light of these findings. The PDA and librarians' books' regression slopes were nearly parallel, which suggests that both sets of books behave similarly as price increases, whereas the slope of the book vendors' selections fell off comparatively precipitously as price increased. The authors would not, of course, suggest that academic libraries should abandon approval plans because of these results: the approval plan infrastructure would be difficult and costly to replace, and approval plans offer a great deal in the way of efficiencies (Nardini 2011). The authors would offer, instead, that the results point toward a beneficial alteration to academic libraries' acquisition activities. The results suggest that libraries ought to bifurcate their acquisitions: the 
approval plan should be used to acquire lower-priced books, with a price cap in place at a point where the circulation performance of book vendors' and librarians' selections is not too widely divergent, and librarians should then be freed from purchasing lower-priced, general interest titles and be encouraged to use their subject expertise and local knowledge to select suitable higher-priced books intended for specialist and more advanced audiences.

Last, the authors would like to return to the issue raised early in the article concerning the amount of anxiety that has surfaced in the library literature concerning the possible coming demise of selection as a library activity. While one cannot conclude that the data presented here support the selection status quo, the data do strongly suggest that librarians as selectors, with their years of subject expertise and local knowledge, do have something to offer academic libraries. That librarians should select all of the books in a library's collection should be a dead idea, but as was broached just above, it would certainly be worthwhile to have expert and experienced librarians making selection decisions where the more expensive materials are concerned.

\section{Notes}

1. Despite the near-universal plaudits for PDA/POD programs, the various costs associated with and the cost-based utility of such programs remain a point of contention, especially the costs of purchasing versus borrowing and the effective cost per use (CPU) value of the books. The consensus on the first issue had been that the costs associated with borrowing and returning books via ILL had approached parity with the costs of purchasing (Alder 2007; Chadwell 2009; Hulsey 2003; Roberts and Cameron 1984), a conclusion based on widely accepted national averages (Jackson 1998, 2004), so ILL PDA should be costeffective (Chadwell 2009). The early consensus opinion on the latter issue had been that the CPU value of ILL PDA books should be better than that of traditionally acquired books because the former circulate significantly more than do the latter (Perdue and Van Fleet 1999; Tyler et al. 2011). Unfortunately, several studies have reported that the prices paid for ILL PDA books (which in some studies have included shipping and handling costs) were higher than the estimated costs associated with the borrowing of ILL returnables (Bertuca et al. 2009; Bombeld and Hanerfeld 2004; Campbell 2006; Chan 2004; Goergen-Doll et al. 2010; Ruppel 2006; Ward 2002; Ward et al. 2003), and at least two studies have noted that the prices paid for ILL PDA books tend to be a bit higher than those paid for books acquired via traditional channels (it should be noted that in neither study did the ILL PDA books benefit from the price discounting given librarians' firm orders and book vendors' selections for the approval plan; Perdue and Van Fleet 1999; Tyler et al. 2011). A recent study by Schroeder (2012), however, has indicated that the costs of PDA and traditionally acquired books were comparable at Brigham Young University. The studies by Tyler et al. (2011) and Schroeder (2012) both have concluded that PDA books provide better use value, but Tyler et al.'s results were expressed only in terms of prices paid per circulation, prices paid per rate of annual turnover, and percentage expected use for percentage of annual turnover versus percentage of dollars spent, as data on the full costs of the books at UNL were unavailable. This approach of using prices paid has the benefit of avoiding "the minefield of administrative and storage costs" (Roberts and Cameron 1984, 36), but it has been criticized as misleading for its failure to address the 
full costs associated with acquiring and adding ILL PDA books to the collection (van Dyk 2011). Van Dyk (2011) has offered that, were processing and overhead costs taken into account, ILL PDA books may cost, on average, 3.3 times as much as an ILL transaction, which would necessitate the ILL PDA books' circulating roughly four times before ILL PDA would become cost-effective in terms of CPU when compared to ILL borrowing. For books with above-average prices (i.e., > \$75), the estimate may run as high as six circulations before ILL PDA breaks even with ILL transaction costs. Schroeder's (2012) results at Brigham Young University counter van Dyk's argument, but it is unclear whether Schroeder used the terms "cost" and "CPU" synonymously with Tyler et al.'s "prices paid" and "prices paid per circulation,." If so, her results would be open to van Dyk's criticism, as well.

2. As Butsch (1946) succinctly put it: “. . usually most of the measures, or traits, or scores, which we would like to predict in educational and social research are so complex that they are determined only in small part by any one other measure, or trait, or score" (p. 118).

3. Note that the Marvin and Virginia Schmid Law Library was, with the exception of a single ILLrequesting graduate student, excluded from this study.

4. A note on the table: Bonferroni inequalities are of use in setting up simultaneous confidence limits (Marriott 1990), and the Bonferroni technique is a method for testing the statistical significance of multiple comparisons that involves adjusting the significance level needed to reject the null hypothesis so as to help one avoid the increased risk of type I errors that comes with multiple comparisons (Vogt 1999). It has been noted that the technique may have several problematic aspects, such as its decreasing of the likelihood of type I errors resulting in an inflating of the likelihood of type II errors (Perneger 1998), but given this study's results, these objections to the technique would appear not to be germane.

\section{References}

Adams, Brian, and Bob Noel. 2008. "Circulation Statistics in the Evaluation of Collection Development." Collection Building 27 (2): 71-3.

Aguilar, William. 1986. "The Application of Relative Use and Interlibrary Demand in Collection Development." Collection Management 8 (1): 15-24.

Alder, Nancy Lichten. 2007. "Direct Purchase as a Function of Interlibrary Loan: Buying Books versus Borrowing." Journal of Interlibrary Loan, Document Delivery E Electronic Reserve 18 (1): 9-15.

Allen, Megan, Suzanne M. Ward, Tanner Wray, and Karl E. Debus-López. 2003. “PatronFocused Services in Three US Libraries: Collaborative Interlibrary Loan, Collection Development and Acquisitions." Interlending E Document Supply 31 (2): 138-41.

Anderson, Kristine J., Robert S. Freeman, Jean-Pierre V. M. H’erubel, Lawrence J. Mykytiuk, Judith M. Nixon, and Suzanne M. Ward. 2002. "Buy, Don't Borrow: Bibliographers' Analysis of Academic Library Collection Development through Interlibrary Loan Requests." Collection Management 27 (3-4): 1-11.

. 2010. “Liberal Arts Books on Demand: A Decade of Patron-Driven Collection Development, Part 1." Collection Management 35 (3-4): 125-41.

Anderson, Rick. 2010. "Let Them Eat ... Everything: Embracing a Patron-Driven Future." Paper presented at the XXXI Annual Charleston Conference, Charleston, South 
Carolina, November 3-6. http://www.slideshare.net/Charleston-Conference/ let-them-eat-everything-by-rick-anderson-university-of-utah

- 2011. "Is Selection Dead? The Rise of Collection Management and the Twilight of Selection." Against the Grain 23 (2): 40-4.

Bates, Marcia J. 1971. “User Studies: A Review for Librarians and Information Scientists." (Eric Document: ED 047 738, Educational Resource Information Clearinghouses). http:// eric.ed.gov/PDFS/ED047738.pdf

Bertuca, Cynthia, Carol Lelonek, Rena Tuohy, Jill Ortner, Anne Bouvier, Sarah Dithomas, Suzanne Hayes, and Sarah, Morehouse. 2009. “Two ILLiad Clients, One Desktop, Purchase on Demand: Sharing a University's Collection, Staff, and Expertise." Journal of Access Services 6 (4): 497-512.

Blecic, Deborah D. 2000. "Monograph Use at an Academic Health Sciences Library: The First Three Years of Shelf Life." Bulletin of the Medical Library Association 88 (2): 145-51.

Bombeld, Madeleine, and Arlene Hanerfeld. 2004. "The Surprising Truth About Faculty Perception and Use of Collection Development Opportunities: One Library's Case Study." Against the Grain 16 (2): 18-22.

Bonn, George S. 1974. “Evaluation of the Collection.” Library Trends 22 (3): 265- 304.

Bracke, Marianne Stowell. 2010. "Science and Technology Books on Demand: A Decade of Patron-Driven Collection Development, Part 2." Collection Management 35 (3-4): 142-50.

Bracke, Marianne Stowell, Jean-Pierre V. M. H’erubel, and Suzanne M. Ward. 2010. “Some Thoughts on Opportunities for Collection Development Librarians." Collection Management 35 (3-4): 255-59.

Britten, William A. 1990. “A Use Statistic for Collection Management: The 80/20 Rule Revisited." Library Acquisitions: Practice \& Theory 14 (2): 183-89.

Brug, Sandy, and Cristi MacWaters. 2004. "Patron-Driven Purchasing from Interlibrary Loan Requests." Colorado Libraries 30 (3): 36-8.

Bulick, Stephen, William N. Sabor, and Roger Flynn. 1979. "Circulation and In-House Use of Books." In Use of Library Materials: The University of Pittsburgh Study, edited by Allen Kent, Jacob Cohen, K. Leon Montgomery, James G. Williams,

Stephen Bulick, Roger R. Flynn, William N. Sabor, and Una Mansfield, 9-55. New York: Marcel Dekker.

Burrell, Quentin L. 1985. “A Note on Ageing in a Library Circulation Model." Journal of Documentation 41 (2): 100-15.

— 1986. "A Second Note on Ageing in a Library Circulation Model: The Correlation Structure." Journal of Documentation 42 (2): 114-28.

- 1987. "A Third Note on Ageing in a Library Circulation Model: Applications to Future Use and Relegation." Journal of Documentation 43 (1): 24-45.

- 1988. "A Simple Empirical Method for Predicting Library Circulations." Journal of Documentation 44 (4): 302-14.

- 1990. “Empirical Prediction of Library Circulations Based on Negative Binomial Processes." In Informetrics 89/90, edited by L. Egghe, and R. Rousseau, 57-64. Amsterdam and New York: Elsevier Science Publishers. 
Butsch, R. L. C. 1946. How to Read Statistics. Milwaukee: Bruce Publishing Company. Campbell, Sharon A. 2006. "To Buy or to Borrow, That is the Question." Journal of Interlibrary Loan, Document Delivery \& Electronic Reserve 16 (3): 35-9.

Carlisle Fountain, Kathleen, and Linda Frederiksen. 2010. “Just Passing Through: PatronInitiated Collection Development in Northwest Academic Libraries." Collection Management 35 (3-4): 185-95.

Carrico, Steven, and Michelle Leonard. 2011. "Patron-Driven Acquisitions and Collection Building Initiatives at UF." Florida Libraries 54 (1): 14-17.

Chadwell, Faye A. 2009. “What's Next for Collection Management and Managers? UserCentered Collection Management." Collection Management 34 (2): 69-78.

Chan, Gayle Rosemary Y. C. 2004. "Purchase Instead of Borrow: An International Perspective." Journal of Interlibrary Loan, Document Delivery \& Information Supply 14 (4): 23-37.

Clendenning, Lynda Fuller. 2001. "Purchase Express for Any User Request." College $\mathcal{E}$ Research Libraries News 62 (1): 16-7.

Comer, Alberta, and Elizabeth Lorenzen. 2007. “Is Purchase on Demand a Worthy Model? Do Patrons Really Know What They Want?" In Charleston Conference Proceedings 2006, edited by Beth R. Bernhardt, Tim Daniels, and Kim Steinle, 171-79. Westport, CT: Libraries Unlimited.

- 2005. "Biz of Acq: Is Purchase-on-Demand a Worthy Model? Do Patrons Really Know What They Want?" Against the Grain 17 (1): 75-8.

Corbett, Tom. 2011. "Patron-Driven Acquisitions in School Libraries: The Promise and the Problems." In Patron-Driven Acquisitions: History and Best Practices, edited by David A. Swords, 95-105. Berlin and Boston: Walter de Gruyter.

Cornell University Library. 2007. “Buy or Borrow.” http://ecommons.cornell.edu/bitstream/1813/12349/1/COL_2007-03-07Buy_or_Borrow.pdf

Crane, Janet. 2011. "ILL-Driven Acquisitions: A Pilot at the University of New Orleans Library." Paper presented at LOUIS Users Conference, Baton Rouge, LA, October 13-14. http://appl003.lsu.edu/ocsweb/louishome.nsf/\$Content/Homepage+News+and+Ann ouncements/\$File/LUC2011AGENDA-Presentations.pdf

Dana, John Cotton. 1896. "Hear the Other Side." Library Journal 21 (12): 1-5.

Davidson, John S. 1943. "The Use of Books in a College Library." College E Research Libraries 4 (3): 294-97.

Dillon, Dennis. 2011. "Texas Demand-Driven Acquisitions: Controlling Costs in a LargeScale PDA Program." In Patron-Driven Acquisitions: History and Best Practices, edited by David A. Swords, 157-67. Berlin and Boston: Walter de Gruyter.

Egan, Nancy. 2007. “Opportunities for Interlibrary Loan and Interlibrary Loan Librarians.” Journal of Interlibrary Loan, Document Delivery \& Electronic Reserve 17 (4): 43-54.

Ellis, Erin L., Nikhat J. Ghouse, Monica Claassen-Wilson, John M. Stratton, and Susanne K. Clement. 2010. "Comparing Approval and Librarian-Selected Monographs: An Analysis of Use." In Library Data: Empowering Practice and Persuasion, edited by Darby Orcutt, 53-68. Santa Barbara, CA: Libraries Unlimited.

Erdman, Donald, Laura Jackson, and Arthur Sinko. 2008. "Zero-Inflated Poisson and ZeroInflated Negative Binomial Models Using the COUNTREG Procedure." Paper 322-2008. Cary, NC: SAS Institute. 
Evans, G. Edward. 1970. "Book Selection and Book Collection Usage in Academic Libraries." Library Quarterly 40 (3): 297-308.

Fenske, Ruth E. 1994. "Evaluation of Monograph Selection in a Health Sciences Library." Bulletin of the Medical Library Association 82 (3): 265-70.

Ferguson, Anthony, Gayle Chan, and Janny Lai. 2008. “User/Patron Driven Ebook Collection Development." Paper presented at Emerging Paradigms for Academic Library E-Book Acquisition and Use: Trends, Challenges and Opportunities, Hong Kong, June 3. http://hdl.handle.net/2031/5154

Fischer, Karen S., and Michael Wright. 2010. “Give 'Em What They Want: Patron-Driven Collection Development." Paper presented at the Iowa Library Association Annual Conference, Coralville, IA, October. http://works.bepress.com/karen_s_fischer/8

Fischer, Karen S., Michael Wright, Kathleen Clatanoff, Hope Barton, and Edward Shreeves. 2012. "Give 'Em What They Want: A One-Year Study of Unmediated Patron-Driven Acquisition of E-books." College E Research Libraries 73 (5): 469-92. http://crl.acrl.org/ content/73/5/469.full.pdf+html

Foss, Michelle. 2007. “Books-On-Demand Pilot Program: An Innovative 'Patron-Centric' Approach to Enhance the Library Collection." Journal of Access Services 5 (1-2): 306-15.

Freedman, David H. 2010a. “The Streetlight Effect.” Discover 31 (6): 55-7.

. 2010b. Wrong: Why Experts* Keep Failing Us - and How to Know When Not to Trust Them. New York: Little, Brown and Company.

Fussler, Herman H., and Julian L. Simon. 1969. Patterns in the Use of Books in Large Research Libraries. Chicago: University of Chicago Press.

Gee, William, and Cindy Shirkey. 2010. “Giving Patrons What They Want: An Analysis of a Thesis and Dissertation Purchase-On-Demand Project at East Carolina University." Journal of Interlibrary Loan, Document Delivery E Electronic Reserve 20 (2): 103-14.

Gibson, Tess M., and Patricia E. Kirkwood. 2009. “A Purchase-On-Demand Pilot Project at the University of Arkansas, for the Proceedings of the Materials Research Society Symposiums." Journal of Interlibrary Loan, Document Delivery \& Electronic Reserve 19 (1): 47-56.

Goergen-Doll, Kerri, and Uta Hussong-Christian. 2011. “Just In Time: For Collaboration and Change." Presented at the Illiad International Conference, Virginia Beach, VA, March 23-25. http://www.atlas-sys.com/ILLiadConf/Presentations/JustInTime.pdf

Goergen-Doll, Kerri, Uta Hussong-Christian, L. Bridges, S. Hoyt, L. Greenfield, and R. Sapon-White. 2010. Purchase on Demand: Recommendations and Final Report to LAMP. Corvallis, OR: Oregon State University; quoted in Hussong- Christian and Goergen-Doll 2010b. “We're listening: ... " http://ir.library.oregonstate.edu/jspui/handle/1957/17311

Grigg, Karen S., Bethany A. Koestner, Richard A. Peterson, and Patricia L. Thibodeau. 2010. "Data-Driven Collection Management: Through Crisis Emerge Opportunities." Journal of Electronic Resources in Medical Libraries 7 (1): 1-12.

Hardesty, Larry. 1981. “Use of Library Materials at a Small Liberal Arts College.” Library Research 3 (3): 261-82.

Hardy, Gary, and Tony Davies. 2007. “Letting the Patrons Choose: Using EBL as a Method for Unmediated Acquisition of Ebook Materials." Paper presented at Information Online 2007: 13th Australian Library and Information Association (ALIA) Exhibition and Conference, Sydney, New South Wales, Australia. http:/ / hdl.handle.net/1959.3/5065 
Herrera, Gail, and Judy Greenwood. 2011. "Patron-Initiated Purchasing: Evaluating Criteria and Workflows." Journal of Interlibrary Loan, Document Delivery E Electronic Reserve 21 (1-2): 9-24.

Hodges, Dracine, Cyndi Preston, and Marsha J. Hamilton. 2010. “Patron-Initiated Collection Development: Progress of a Paradigm Shift." Collection Management 35 (3-4): 208-21.

Holley, Richard P., and Kalyani Ankem. 2005. "The Effect of the Internet on the Out-of-Print Book Market: Implications for Libraries." Library Collections, Acquisitions, E Technical Services 29 (2): 118-39.

Hostetler, Marna. 2010. "Purchase-On-Demand: An Overview of the Literature." Against the Grain 22 (2): 46-47.

Houle, Louis. 2004. “Convergence Between Interlibrary Loan and Acquisitions: A Science and Engineering Library Experience." Paper presented at Library Management in Changing Environment: Proceedings of the 25th Annual IATUL Conference, The Library of Cracow University of Technology, Kraków, Poland, May 30-June 3. http://www. iatul.org/doclibrary/public/Conf Proceedings/2004/Louis20Houle.pdf

Hulsey, Richard. 2003. "Purchase On Demand: A Better Customer Service Model." Library Journal 128 (10): 77.

Hussong-Christian, Uta, and Kerri Goergen-Doll. 2010a. “Buy Request: Just In Time v. Just In Case at OSU Libraries." Paper presented at the Acquisitions Institute at Timberline Lodge, Timberline Lodge, OR, May 15-18. http://hdl.handle.net/1957/16091

_. 2010b. "We're Listening: Using Patron Feedback to Assess and Enhance Purchase on Demand." Journal of Interlibrary Loan, Document Delivery E Electronic Reserve 20 (5): 319-35.

- 2011. "Buy Request: Just In Time v. Just In Case at OSU Libraries (Updated)." Paper presented at the Oregon Libraries Association Conference, Salem, OR, April 7. http://hdl.handle.net/1957/20885

Jackson, Mary Ellen. 1989. “Library to Library.” Wilson Library Bulletin, 64 (4): 88- 89.

- 1998. Measuring the Performance of Interlibrary Loan Operations in North American Research and College Libraries. Washington, DC: Association of Research Libraries.

. 2004. Assessing ILL/DD Services: New Cost-Effective Alternatives. Washington, DC: Association of Research Libraries. http:/ / archive.org/details/assessingillddse00jackrich

Jain, A. K. 1969. "Sampling and Data Collection Methods for a Book-Use Study." Library Quarterly 39 (3): 245-52.

Jain, A. K., F. F. Leimkuhler, and V. L. Anderson. 1969. “A Statistical Model of Book Use and Its Application to the Book Storage Problem." Journal of the American Statistical Association 64 (328): 1211-224.

Jenks, George M. 1976. "Circulation and Its Relationship to the Book Collection and Academic Departments." College \& Research Libraries 37 (2): 145-52.

Jones, Douglas. 2011. “On-Demand Information Delivery: Integration of Patron- Driven Acquisition Into a Comprehensive Information Delivery System." Journal of Library Administration 51 (7-8): 764-76.

Knievel, Jennifer E., Heather Wicht, and Lynn Silipigni Connaway. 2006. "Use of Circulation Statistics and Interlibrary Loan Data in Collection Management." College E Research Libraries 67 (1): 35-49. 
Knoll, Robert E. 1995. Prairie University: A History of the University of Nebraska. Lincoln: University of Nebraska Press and The Alumni Association of the University of Nebraska-Lincoln.

Kuhn, Maria Silva. 2004. "The Intersection Where Collection Development and Acquisitions Meet Interlibrary Loan." Against the Grain 16 (2): 28-30.

Lancaster, F. W. 1982. "Evaluating Collections By Their Use." Collection Management 4 (1-2): 15-43.

Lenares, Deborah, and Emilie Delquie. 2010. “Give the People What They Want: Patron Driven Acquisition: Results and Reflections on a Survey Completed by Publishers Communication Group." Paper presented at the STM Spring Conference, Le Meridien Cambridge-MIT, Cambridge, MA, April 21-29. http://www.stmassoc.org/2010_04_27 Spring_Conference_Lenares_Patron_Driven_Acquisition.pdf

Levine-Clark, Michael. 2011. "Building a Demand-Driven Collection: The University of Denver Experience." In Patron-Driven Acquisitions: History and Best Practices, edited by David A. Swords, 45-60. Berlin and Boston: Walter de Gruyter.

Littman, Justin, and Lynn Silipigni Connaway. 2004. “A Circulation Analysis of Print Books and E-books in an Academic Research Library." Library Resources E Technical Services 48 (4): 256-62.

Lotlikar, Sarojini D. 1997. “Collection Assessment at the Ganser Library: A Case Study.” Collection Building 16 (1): 24-9.

Lugg, Rick. 2011. "Collecting for the Moment: Patron-Driven Acquisitions as a Disruptive Technology." In Patron-Driven Acquisitions: History and Best Practices, edited by David A. Swords, 7-22. Berlin and Boston: Walter de Gruyter.

McGrath, William E. 1971. "Correlating the Subjects of Books Taken Out of and Books Used Within an Open-Stack Library." College E Research Libraries 32 (4): 280-85.

McGrath, William E., Ralph C. Huntsinger, and Gary R. Barber. 1969. “An Allocation Formula Derived from a Factor Analysis of Academic Departments." College $\mathcal{E}$ Research Libraries 30 (1): 51-62.

McHone-Chase, Sarah M. 2010. "Examining Change Within Interlibrary Loan." Journal of Interlibrary Loan, Document Delivery \& Electronic Reserve 20 (3): 201-06.

Manley, Robert N. 1969. Centennial History of the University of Nebraska: Frontier University (1869-1919), vol. I. Lincoln: University of Nebraska Press.

Marriott, F. H. C. 1990. A Dictionary of Statistical Terms, 5th ed. New York: John Wiley and Sons.

Miller, William. 2011. "Patron-Driven Acquisitions (PDA): The New Wave in Book Acquisitions Is Coming." Library Issues: Briefings for Faculty and Administrators 31 (5): 1-4.

Mills, Terry R. 1982. The University of Illinois Film Center Collection Use Study. Urbana: University of Illinois, CAS Paper (ERIC Document: ED227821).

Mouyal, Katalin Fay. 2005. “A Balancing Act: User Demand versus Programs Driven Collection Management at a Small, Regional Academic Library." Collection Management 30 (4): 43-57.

Murphy, Molly, and Karen Rupp-Serrano. 1999. “Interlibrary Loan and Document Delivery: Lessons to be Learned." Journal of Library Administration 28 (2): 15-24. 
Nardini, Bob. 2011. “Approval Plans and Patron Selection: Two Infrastructures.” In PatronDriven Acquisitions: History and Best Practices, edited by David A. Swords, 23-43. Berlin and Boston: Walter de Gruyter.

Nixon, Judith M., Robert S. Freeman, and Suzanne M. Ward. 2010. “Patron-Driven Acquisitions: An Introduction and Literature Review." Collection Management 35 (3-4): 119-24.

Nixon, Judith M., and E. Stewart Saunders. 2010. "A Study of Circulation Statistics of Books On Demand: A Decade of Patron-Driven Collection Development, Part 3." Collection Management 35 (3-4): 151-61.

Oberlander, Cyril. 2006. "Transforming the Document Delivery and Resource Sharing Engine." Paper presented at "Libraries: Dynamic Engines for the Knowledge and Information Society," the World Library and Information Congress, 72nd IFLA General Conference and Council, Seoul, South Korea, August 20-24. http://archive.ifla.org/IV/ ifla72/papers/073-Oberlander-en.pdf

Ochola, John N. 2002. "Use of Circulation Statistics and Interlibrary Loan Data in Collection Management." Collection Management 27 (1): 1-13.

Osorio, Nestor L. 2011. “A User's Participatory Selecting Model: Librarians Point of Views.” Paper presented at the Illinois Library Association Annual Meeting, Rosemont, IL, October 18-20. http:// eprints.rclis.org/handle/10760/16507

Peasgood, Adrian N. 1986. "Towards Demand-Led Book Acquisitions? Experiences in the University of Sussex Library." Journal of Librarianship and Information Science 18 (4): 242-56.

Perdue, Jennifer, and James A. Van Fleet. 1999. “Borrow or Buy? Cost-Effective Delivery of Monographs." Journal of Interlibrary Loan, Document Delivery E Information Supply 9 (4): 19-28.

Perneger, Thomas V. 1998. “What's Wrong with Bonferroni Adjustments.” British Medical Journal 316 (7139): 1236-238.

Posner, Beth. 2007. "Library Resource Sharing in the Early Age of Google." Library Philosophy and Practice 9 (3): 1-10. http://www.webpages.uidaho.edu/ mbolin/posner.pdf

Price, Jason, and John McDonald. 2009. “Beguiled by Bananas: A Retrospective Study of the Usage \& Breadth of Patron vs. Librarian Acquired Ebook Collections." Paper presented at "Presentation on E-book Acquisition at Academic Libraries" at 2011 Charleston Conference: "Issues in book and serial acquisition," Charleston, SC, November 2-5. http:// ccdl.libraries.claremont.edu/cdm/singleitem/collection/lea/id/175

Pritchard, S. J. 1980. "Purchase and Use of Monographs Originally Requested on Interlibrary Loan in a Medical School Library." Library Acquisitions: Practice and Theory 4 (2): 135-9.

Rathbone, Frances L. 1909. “Borrower and His Book." New York Libraries 1: 228-32.

Rawlinson, Nora. 1981. “Give 'Em What they Want!” Library Journal 106 (20): 2188-190.

Reighart, Renee, and Cyril Oberlander. 2008. “Exploring the Future of Interlibrary Loan: Generalizing the Experience of the University of Virginia, USA." Interlending $\mathcal{E}$ Document Supply 36 (4): 184-90.

Reynolds, Leslie J., Carmelita Pickett, Wyoma Vanduinkerken, Jane Smith, Jeanne Harrell, and Sandra Tucker. 2010. "User-Driven Acquisitions: Allowing Patron Requests to Drive Collection Development in an Academic Library." Collection Management 35 (3-4): 244-54. 
Richey, Nancy. 2010. "I Need This Now! Interlibrary Loan Meets Collection Development on the Patron Access Road." Against the Grain 22 (1): 8-14.

Roberts, Michael, and Kenneth J. Cameron. 1984. “A Barometer of 'Unmet Demand': Interlibrary Loans Analysis and Monographic Acquisitions." Library Acquisitions: Practice and Theory 8 (1): 31-42.

Rottmann, F. K. 1991. “To Buy or to Borrow: Studies of the Impact of Interlibrary Loan on Collection Development in the Academic Library." Journal of Interlibrary Loan E Information Supply 1 (3): 17-27.

Ruppel, Margie. 2006. “Tying Collection Development's Loose Ends with Interlibrary Loan." Collection Building 25 (3): 72-7.

Schroeder, Rebecca. 2012. "When Patrons Call the Shots: Patron-Driven Acquisition at Brigham Young University." Collection Building 31 (1): 11-14.

Shen, Lisa, Erin Dorris Cassidy, Eric Elmore, Glenda Griffin, Tyler Manolovitz, Michelle Martinez, and Linda M. Turney. 2011. "Head First Into the Patron-Driven Acquisition Pool: A Comparison of Librarian Selections versus Patron Purchases." Journal of Electronic Resources Librarianship 23 (3): 203-18.

Slater, Robert. 2009. “E-books or Print Books, 'Big Deals' or Local Selections - What Gets More Use?" Library Collections, Acquisitions, E Technical Services 33 (1): 31-41.

Smith, Elena S. 2011. "Power and Practice in Academic Library Materials Selection Paradigms." SLIS Student Research Journal 1 (2): Article 6. http://scholarworks.sjsu.edu/ slissrj/vol1/iss2/6/

Spitzform, Peter. 2011a. "Patron-Driven Acquisition: Collecting as If Money and Space Mean Something." Against the Grain 23 (3): 20-4.

- 2011b. "The User Knows Best." Paper presented at NETSL Annual Spring Conference, College of Holy Cross, Worcester, MA, April 8. http:/ / www.nelib.org/Resources/ Documents/NETSL/SpitzformPDAnets12011.pdf.

Stevens, Joseph J. 2000. "Interaction Effects in Regression." Accessed February 16, 2012. http://pages.uoregon.edu/stevensj/MRA/interaction.pdf

Sutton, Lynn. 2003. “Collaborating with Our Patrons: Letting the Users Select.” Paper presented at "Learning to Make a Difference: The Eleventh National Conference of the Association of College and Research Libraries," Charlotte, NC, April 10-13. http://www.ala. org/acrl/files/conferences/pdf/lsutton.PDF

Tague, Jean, and Isola Ajiferuke. 1987. "The Markov and the Mixed-Poisson Models of Library Circulation Compared." Journal of Documentation 43 (3): 212-31.

Teaff, E. A. 2011. “Purchase On Demand (POD) \& Interlibrary Loan." Paper presented at The 13th Annual VIVA Interlibrary Loan Community Forum, Sweet Briar College, Sweet Briar, VA, July 15. http://viva-ill.pbworks.com/w/file/42429086/PurchaseonDemandPOD.pptx

Tucker, James Cory. 2009. "Collection Assessment of Monograph Purchases at the University of Nevada, Las Vegas Libraries." Collection Management 34 (3): 157-81.

Tyler, David C. 2011. "Patron-Driven Purchase on Demand Programs for Printed Books and Similar Materials: A Chronological Review and Summary of Findings." Library Philosophy and Practice, Paper 635. http:/ / unllib.unl.edu/LPP/tyler.pdf 
Tyler, David C., Joyce C. Melvin, Yang Xu, MaryLou Epp, and Anita M. Kreps. 2011. “Effective Selectors? Interlibrary Loan Patrons as Monograph Purchasers: A Comparative Examination of Price and Circulation-Related Performance." Journal of Interlibrary Loan, Document Delivery \& Electronic Reserve 21 (1-2): 57-90; http://digitalcommons.unl.edu/ libraryscience/241/

Tyler, David C., MaryLou Epp, Anita M. Kreps, Joyce C. Melvin, and Susan M. Leach. 2009. "SUMMARY BRIEF: UNL Libraries 2003/04-2007/08 Acquisitions: Performance of Non-Serial Volumes Available for Checkout." Unpublished white paper, University of Nebraska-Lincoln Libraries. http:/ / digitalcommons.unl.edu/librarywhitepapers/5/

Tyler, David C., Yang Xu, Joyce C. Melvin, MaryLou Epp, and Anita M. Kreps. 2010. “Just How Right Are the Customers? An Analysis of the Relative Performance of Patron-Initiated Interlibrary Loan Monograph Purchases." Collection Management 35 (3-4): 162-79; http://digitalcommons.unl.edu/libraryscience/230/

University of Nebraska-Lincoln, Office of Institutional Research and Planning. 2005-2009. University of Nebraska-Lincoln Fact Book. Lincoln, NE: The Office. http:/ / irp.unl.edu/factbooks.html

University of Nebraska-Lincoln Libraries. 2011. "Welcome to the UNL University Libraries." http://libraries.unl.edu/about

van Dyk, Gerrit. 2011. “Interlibrary Loan Purchase-On-Demand: A Misleading Literature." Library Collections, Acquisitions, \& Technical Services 35 (2-3): 83-89.

Vogt, W. Paul. 1999. Dictionary of Statistics and Methodology: A Nontechnical Guide for the Social Sciences, 2nd ed. Thousand Oaks, CA: Sage Publications.

Ward, Suzanne M. 2002. “Books on Demand: Just-In-Time Acquisitions.” The Acquisitions Librarian 14 (27): 95-107.

—. 2011. "Patron-Driven Acquisitions (PDA): Origins, Implementation, Future." Paper presented at NOTSL Spring Meeting, Parma, OH, June 17. http://notsl.files.wordpress. com/2011/07/2011-spring-ward.pdf

Ward, Suzanne M., Tanner Wray, and Karl E. Debus-López. 2003. "Collection Development Based on Patron Requests: Collaboration Between Interlibrary Loan and Acquisitions." Library Collections, Acquisitions, \& Technical Services 27 (2): 203-13.

Watson, Paula D. 2004. “Alternative Acquisition Routes." Library Technology Reports 40 (6): 59-67.

Way, Doug. 2009. “The Assessment of Patron-Initiated Collection Development via Interlibrary Loan at a Comprehensive University." Journal of Interlibrary Loan, Document Delivery E Electronic Reserve 19 (4): 299-308.

Way, Doug, and Julie Garrison. 2011. “Financial Implications of Demand-Driven Acquisitions: A Case Study of the Value of Short-Term Loans." In Patron-Driven Acquisitions: History and Best Practices, edited by David A. Swords, 137-56. Berlin and Boston: Walter de Gruyter.

Wexelbaum, Rachel, and Virginia Heinrich. 2011. “Patron Driven Acquisitions Systems: How Many Cool Kids Are Doing It?" Paper presented at the PALS Acquisitions/Serials/Cataloging Workday, Metropolitan State University, St. Paul, MN, April 28. http:// www.mnpals.org/sites/default/files/2011Patron DrivenAcquisitions Systems.pdf 
Willett, Charles. 1998. "Consider the Source: A Case Against Outsourcing Materials Selection in Academic Libraries." Collection Building 17 (2): 91-95.

Zopfi-Jordan, David. 2008. "Purchasing or Borrowing: Making Interlibrary Loan Decisions That Enhance Patron Satisfaction." Journal of Interlibrary Loan, Document Delivery E Electronic Reserve 18 (3): 387-94.

\section{Appendix}

Table A1. Negative Binomial Regression Predicting Circulation $(N=63,732)$

\begin{tabular}{|c|c|c|c|c|c|c|c|c|c|c|c|c|}
\hline & \multicolumn{12}{|c|}{ Circulations } \\
\hline & \multicolumn{3}{|c|}{ Model 1} & \multicolumn{3}{|c|}{ Model 2} & \multicolumn{3}{|c|}{ Model 3} & \multicolumn{3}{|c|}{ Model 4} \\
\hline & $b$ & & $S E$ & $b$ & & $S E$ & $b$ & & $S E$ & $b$ & & $S E$ \\
\hline Intercept & .671 & & .03 & -.096 & & .04 & -.127 & & .06 & -.093 & & .16 \\
\hline \multicolumn{13}{|l|}{ ORDER TYPE ${ }^{a}$} \\
\hline Book Vendor & -.613 & $* * *$ & .04 & -.619 & $* * *$ & .03 & -.431 & & .06 & -.769 & $* * *$ & .16 \\
\hline Librarian & -.354 & $* * * \mathrm{~b}$ & .04 & -.370 & $* * * b$ & .03 & -.331 & & .06 & -.072 & & .17 \\
\hline YEARS A VAILABLE & & & & .272 & $* * *$ & .00 & .272 & $* * *$ & .00 & .272 & $* * *$ & .00 \\
\hline BOOK PRICE & & & & -.003 & $* * *$ & .00 & -.002 & * & .05 & -.003 & $* * *$ & .00 \\
\hline Book Vendor & & & & & & & -.004 & $* * *$ & .05 & & & \\
\hline Librarian & & & & & & & -.001 & & .05 & & & \\
\hline \multicolumn{13}{|l|}{ SUBJECT AREA ${ }^{c}$} \\
\hline Philosophy & & & & -.356 & $* * *$ & .04 & -.399 & $* * *$ & .04 & -.136 & & .25 \\
\hline Book Vendor & & & & & & & & & & -.087 & & .26 \\
\hline Librarian & & & & & & & & & & -.057 & & .26 \\
\hline Religious Studies & & & & -.264 & $* * *$ & .04 & -.311 & $* * *$ & .04 & -.579 & * & .23 \\
\hline Book Vendor & & & & & & & & & & .505 & * & .23 \\
\hline Librarian & & & & & & & & & & -.022 & & .24 \\
\hline History & & & & -.104 & $* * *$ & .03 & -.165 & $* * *$ & .03 & -.275 & & .19 \\
\hline Book Vendor & & & & & & & & & & .376 & & .19 \\
\hline Librarian & & & & & & & & & & -.261 & & .20 \\
\hline Music & & & & .462 & $* * *$ & .04 & .414 & $* * *$ & .04 & .202 & & .30 \\
\hline Book Vendor & & & & & & & & & & .477 & & .30 \\
\hline Librarian & & & & & & & & & & -.094 & & .31 \\
\hline Art, Architecture and & lotogra & & & .278 & $* * *$ & .03 & .233 & $* * *$ & .03 & .140 & & .20 \\
\hline Book Vendor & & & & & & & & & & .176 & & .20 \\
\hline Librarian & & & & & & & & & & -.080 & & .20 \\
\hline Language and Litera & & & & -.212 & $* * *$ & .03 & -.254 & $* * *$ & .03 & -.090 & & .19 \\
\hline Book Vendor & & & & & & & & & & .084 & & .19 \\
\hline Librarian & & & & & & & & & & -.465 & * & .19 \\
\hline Library and Informat & Scienc & & & -.086 & & .08 & -.130 & & .08 & -.205 & & .35 \\
\hline Book Vendor & & & & & & & & & & .297 & & .38 \\
\hline Librarian & & & & & & & & & & -.174 & & .36 \\
\hline
\end{tabular}


Table A1. (Continued)

\begin{tabular}{|c|c|c|c|c|c|c|c|c|c|c|c|c|}
\hline & & & & & & Circu & & & & & & \\
\hline & & Mod & ll 1 & & Mode & & & Mod & & & Iodel & \\
\hline & $b$ & & $S E$ & $b$ & & $S E$ & $b$ & & $S E$ & $b$ & & $S E$ \\
\hline Psychology & & & & .193 & $* * *$ & .05 & .149 & $* * *$ & .05 & .385 & & .23 \\
\hline Book Vendor & & & & & & & & & & -.080 & & .24 \\
\hline Librarian & & & & & & & & & & -.475 & & .24 \\
\hline Social Sciences and Stat & stics & & & .612 & $* * *$ & .08 & .575 & $* * *$ & .08 & .330 & & .41 \\
\hline Book Vendor & & & & & & & & & & .573 & & .44 \\
\hline Librarian & & & & & & & & & & -.058 & & .42 \\
\hline Business and Economic & & & & -.137 & $* * *$ & .03 & -.186 & $* * *$ & .03 & -.098 & & .20 \\
\hline Book Vendor & & & & & & & & & & .064 & & .20 \\
\hline Librarian & & & & & & & & & & -.266 & & .21 \\
\hline Sociology & & & & .112 & $* * *$ & .03 & .068 & * & .03 & .158 & & .19 \\
\hline Book Vendor & & & & & & & & & & .105 & & .19 \\
\hline Librarian & & & & & & & & & & -.344 & & .19 \\
\hline Political Science & & & & -.195 & $* * *$ & .04 & -.243 & $* * *$ & .04 & -.189 & & .25 \\
\hline Book Vendor & & & & & & & & & & .161 & & .25 \\
\hline Librarian & & & & & & & & & & -.323 & & .25 \\
\hline Law & & & & -.109 & * & .05 & -.167 & $* * *$ & .05 & -.139 & & .25 \\
\hline Book Vendor & & & & & & & & & & .235 & & .26 \\
\hline Librarian & & & & & & & & & & -.424 & & .27 \\
\hline Education & & & & -.009 & & .03 & -.054 & & .03 & .074 & & .24 \\
\hline Book Vendor & & & & & & & & & & .089 & & .24 \\
\hline Librarian & & & & & & & & & & -.396 & & .24 \\
\hline Sciences and Mathemat & & & & .209 & $* * *$ & .03 & .201 & $* * *$ & .03 & .293 & & .19 \\
\hline Book Vendor & & & & & & & & & & .080 & & .19 \\
\hline Librarian & & & & & & & & & & -.399 & * & .19 \\
\hline Medicine & & & & .138 & $* * *$ & .03 & .104 & $* * *$ & .03 & .181 & & .19 \\
\hline Book Vendor & & & & & & & & & & .110 & & .20 \\
\hline Librarian & & & & & & & & & & -.341 & & .20 \\
\hline Agriculture & & & & .020 & & .04 & -.015 & & .04 & .277 & & .41 \\
\hline Book Vendor & & & & & & & & & & -.116 & & .42 \\
\hline Librarian & & & & & & & & & & -.547 & & .42 \\
\hline Dispersion Parameter & 1.142 & $* * *$ & .01 & .927 & $* * *$ & .01 & .922 & $* * *$ & .01 & .917 & $* * *$ & .01 \\
\hline
\end{tabular}

a. Interlibrary Loan sco $_{\text {is }}$ the omitted reference group for order type.

b. The effect for librarian is significantly different from the effect for book vendor.

c. Engineering and technology is the omitted reference group for subject area.

${ }^{*} p<.05$

$* * p<.01$

$* * * p<.001$ 